\title{
Havran v egyptské kultuře
}

\author{
Břetislav Vachala \\ Český egyptologický ústav Univerzity Karlovy v Praze a Káhiře, Celetná 20, 11000 Praha 1
}

\section{THE RAVEN IN EGYPTIAN CULTURE}

ABSTRACT Living close to nature along the Nile River, the ancient Egyptians depended on an intimate knowledge of the local fauna and flora for their livelihoods. And in fact, they became exceedingly familiar with the avian world around them, including the ravens (family Corvidae). The earliest extant representation of ravens is presented on a fragment of the "Battlefield Palette" (cca 3150 BC; fig. 1). The realistic representations of ravens and crows on figured ostraca dating from the Ramesside Period are well known (figs. 2, 3). Moreover, two extraordinary scenes present an episode from an unknown fable (fig. 6) and a parody of weighting the deceased's heart in front of the god Osiris (figs. 4, 5). Probably the most accurate example of the raven in Egyptian art appears on a 12 Dynasty pectoral where two ravens are pictured in place of falcons, symbol of the god Horus, i.e. the king (fig. 7). The ancient Egyptians assigned the raven both positive and negative (cf. the Demotic dreambook of Papyrus Carlsberg XIV, f.) roles. A similar attitude of mind towards the raven is attested in the Arab Middle Ages: on the one hand, the raven as a symbol of separation, sadness and death (e.g. the poems by Antar ibn Shaddad, Duraid ibn as-Simma, al-Ahwas), on the other hand, a symbol of hope and welfare (in the Egyptian folk-songs).

KEY WORDS raven; Ancient Egypt; arabic poetry; ostraca; papyri; art

ABSTRAKT Staří Egyptané žijící podél Nilu měli vždy úzký vztah k prŕírodě a byli přirozeně závislí na důvěrné znalosti místní fauny a flóry. Dobře byli obeznámeni také se světem ptáků, včetně havranů (čeled’ Corvidae). Nejstarší zobrazení havranů se nachází na zlomku „Palety bojiště “" (okolo 3150 př. n. 1.; obr. 1). Známá jsou realistická vyobrazení havranů a vran na figurálních ostrakách z Ramessovské doby (obr. 2, 3). Kromě toho se dochovaly dvě neobvyklé scény s epizodou z neznámé bajky (obr. 6) a s parodií vážení srdce zemřelého před bohem Usirem (obr. 4, 5). Zřejmě nejvěrnější zpodobení havrana v egyptském umění se objevuje na pektorálu z 12. dynastie, kde dva havrani zastupují sokoly, symbol boha Hora, to jest krále (obr. 7). Dávní Egyptané přisoudili havranovi pozitivní i negativní (srovnej démotický snáŕ na papyru Carlsberg č. XIV, f.) úlohu. Podobný postoj k havranovi je doložen i v arabském středověku: na jedné straně symbolizuje rozloučení, smutek a smrt (např́klad básně Antara ibn Šaddáda, Durajda ibn as-Simmy, al-Ahwase), na druhé straně naději a dobro (v egyptských lidových písních).

KLÍČOVÁ SLOVA havran; starý Egypt; arabská poezie; ostraka; papyry; umění

„Je mi líto, že havran sedící na stromě je neštastný a že ho lidé na celém světě nenávidí, ačkoli jsem neslyšel o tom, že by někdy někomu ubližil."

Takto líčí smutný osud havrana, který v Egyptě symbolizuje smutek, samotu a odloučenost, jeden z nejvýznamnějších představitelů moderní egyptské prózy Bahá Táhir (Ondráš 2003, 43). Činí tak ústy hrdiny své povídky Včera se mi o tobě $z$ dálo, která vyšla $\mathrm{v}$ Káhiře $\mathrm{v}$ roce 1984 . Jeho slovům se nemůžeme divit, když již uznávaní staroarabští básníci spojovali havrana nejen s rozlukou, ale vưbec s neštěstím, nepříznivým osudem a se smrtí. Jako ukázka nám poslouží verše ze staroarabské romance o předislámském básníkovi Antarovi ibn Šaddádovi (asi 525-615), která je obdobou hrdinských epo- pejí sepsaných v různých dobách a kulturních oblastech světa. Když byl Antar „hluboce zasažen láskou a vášní šílel, “ rríkal si mimo jiné (Petráček 1968, 222):

„Havrane smutku! V sitě

nelapil jsem tě dosud, nedotk jsem se tvých mládiat proč stíháš mě jak osud?"

Na druhé straně je však havran v arabském lidovém myšlení chápán i jako symbol príznivé věštby a proroctví, a tedy naděje a dobra (Ondráš 2003, 42).

Nejstarší egyptské zobrazení havranů (či vran) se nachází na břidlicové tak zvané paletě bojiště z doby okolo roku 3150 


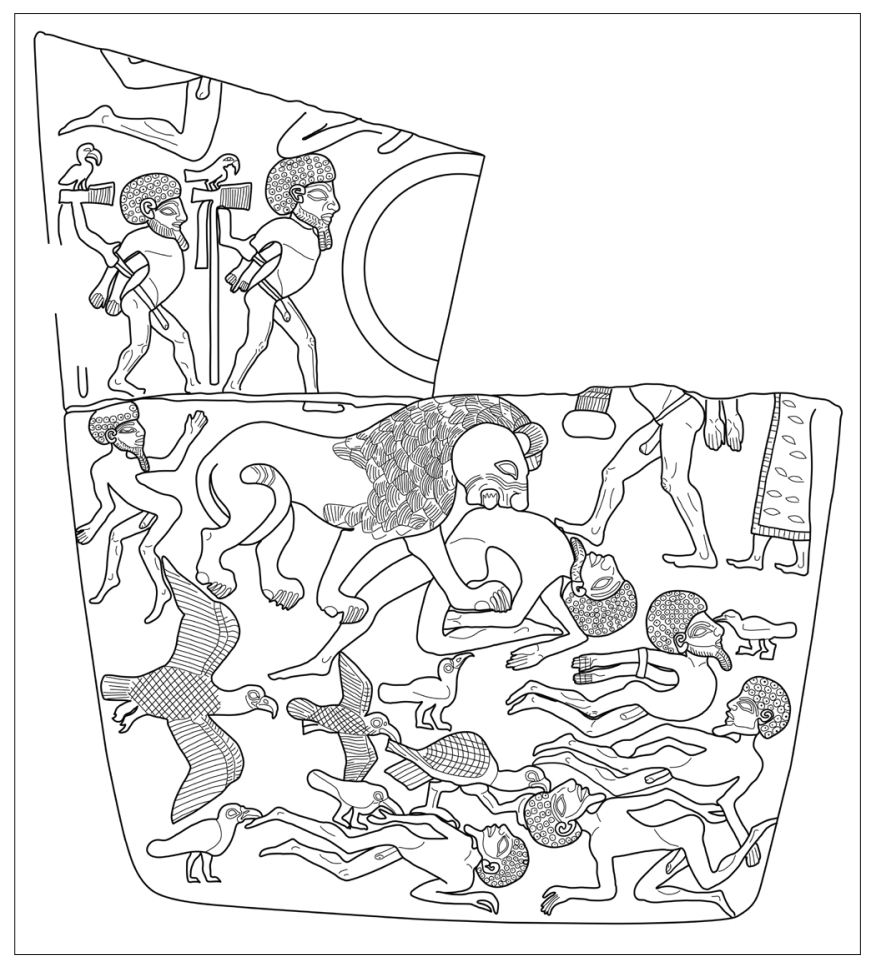

Obr. 1. Anonym, „Paleta bojiště“, kolem roku 3150 př. n. 1., 0. dynastie, břidlicový reliéf, výška 32,8 cm, naleziště: Abydos, Egypt, uloženo: Britské muzeum v Londýně (dolní část), Velká Británie, Muzeum Ashmolean v Oxfordu (horní část), Velká Británie.

Částečně dochovanou paletu na roztírání líčidel zdobí triumfální scéna, kdy po skončené bitvě panovník v podobě lva požírá neprrítele, zatímco těla ostatních padlých nepřátel otrhávají supi a havrani. Nahoře vlevo přivádějí egyptská krajová božstva dva neprrátele se svázanýma rukama za zády. (Kresba: Jolana Malátková.)

Fig. 1. The so-called "Battlefield Palette", cca 3150 BC, Dynasty 0, raised relief in siltstone, h. $32.8 \mathrm{~cm}$, probably from the temple at Abydos. The upper part in the Ashmolean Museum, Oxford, the lower part in the British Museum, London.

The scene of the votive palette shows the grim aftermath of a battle. The king as a lion is devouring a slain foe meanwhile the bodies of enemies are being feasted by a whole flock of vultures and ravens. (Drawing: Jolana Malátková.)

př̀ n. 1. (Malek 2003, 28; obr. 1). Z oboustranně zdobené palety, která měla oslavný a pamětní ráz a sloužila jako votivní chrámový dar pravděpodobně určený ochrannému bohu abydoského královského pohřebiště Chontamentejovi, se dochovala bohužel jen její spodní část s vyobrazením předdynastického panovníka v podobě lva požírajícího po skončené vítězné bitvě ležícího neprítele. Na těla dalších poražených nepřátel, rozsetá po bitevním poli, se mezitím slétají nebo je už otrhávají supi a havrani. Smyslem této scény bylo nejen připomenout historické vítězství blíže neznámého panovníka, ale také zdo̊raznit jeho důležitou úlohu garanta řádu pravdy, práva a spravedlnosti (maat), který staroegyptský vládce - bůh žijící na zemi naplňoval i tím, že dennodenně potíral síly zla a chaosu, které ztělesňovali také cizí nepřátelé (Moers et al. 2004, 25, 31-32).

Zmíněná scéna trhání mrtvých těl dravými ptáky je dostatečně známá. Právě na bitevních polích byla mnohokrát pozo-

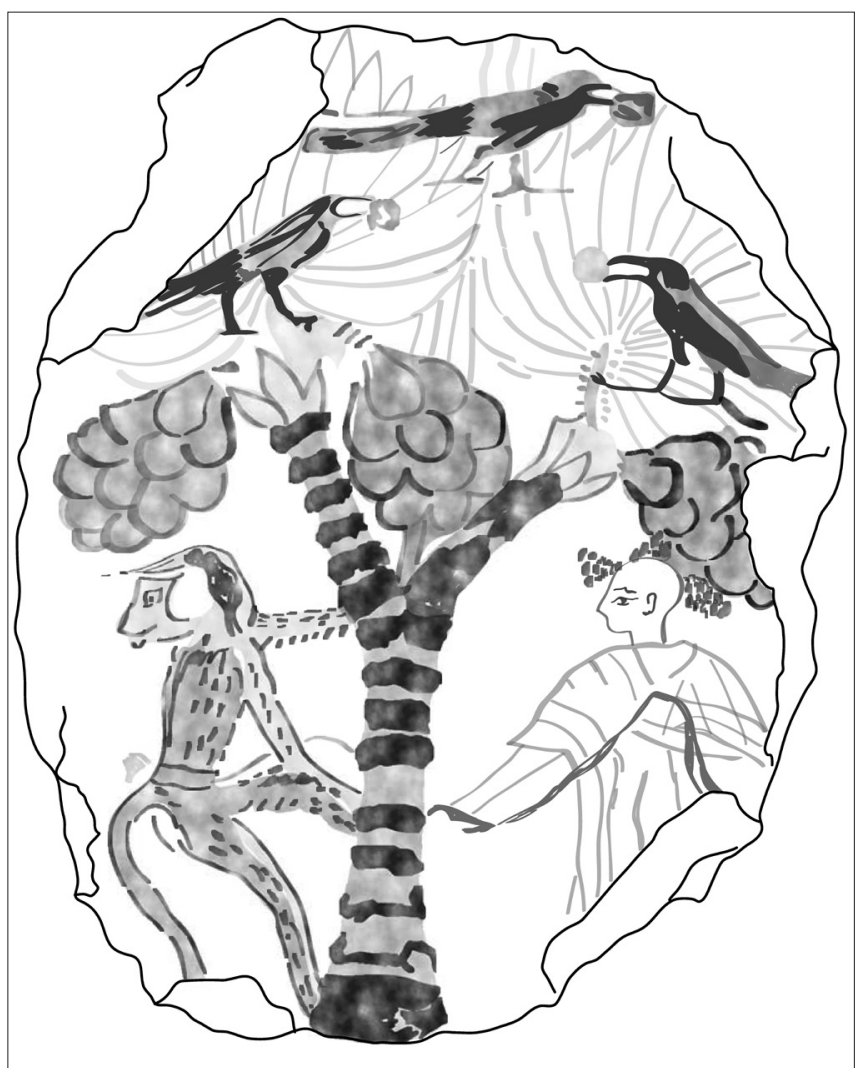

Obr. 2. Anonym, „Havrani a opice na palmě dumové“, mezi lety 1292-1078 př. n. 1., 19.-20. dynastie, kresba na vápencovém ostraku, rozměry $13,3 \times 11 \mathrm{~cm}$, naleziště: Dér el-Medína, Egypt, uloženo: Francouzský ústav orientální archeologie v Káhiř̌e, Egypt.

Pavián vylézá na palmu dumovou, na jejíž větvích stojí tři havrani (nebo vrány), kteří se již zmocnili ořechů. Vpravo dole stojí muž oděný do dlouhého šatu. (Kresba: Jolana Malátková.)

Fig. 2. Drawing of a limestone ostracon showing a baboon climbing a dom palm (Hyphaene thebaica) and three ravens (or crows) feeding on dom nuts above. Between 1272-1078 BC, Dynasty 19-20, dimensions $13.3 \times 11 \mathrm{~cm}$, from Deir el-Medina. The French Institute of Oriental Archaeology, Cairo. (Drawing: Jolana Malátková.)

rována mrtvá těla lidí, koní a velbloudů, z nichž vyletěli supi, havrani a luňáci. Dochovalo se i staroarabské literární líčení v podobě veršů předislámského básníka Durajda ibn asSimmy (někdy v rozmezí let 530-630), představitele principů a ideálů staroarabského beduínství (Růžička 1930, 18; Oliverius 1995, 75-76):

„Tam na poli jsme bitevním jich reky zanechali, již spoutáni neb sraženi kmen ku pomoci zvali. Jich hlavy sečem mečem svým my v otevřeném boji a kopí naše zas a zas svou žizeň na nich kojí. Zřišs sžernalými tvářemi kol jezdců ležet kupy, a kolem krouži havrani, houf hyen, lační supi."

Působivé verše s motivem havrana rvoucího umírající tělo najdeme v již citované romanci o Antarovi (Petráček 1977, 42): 


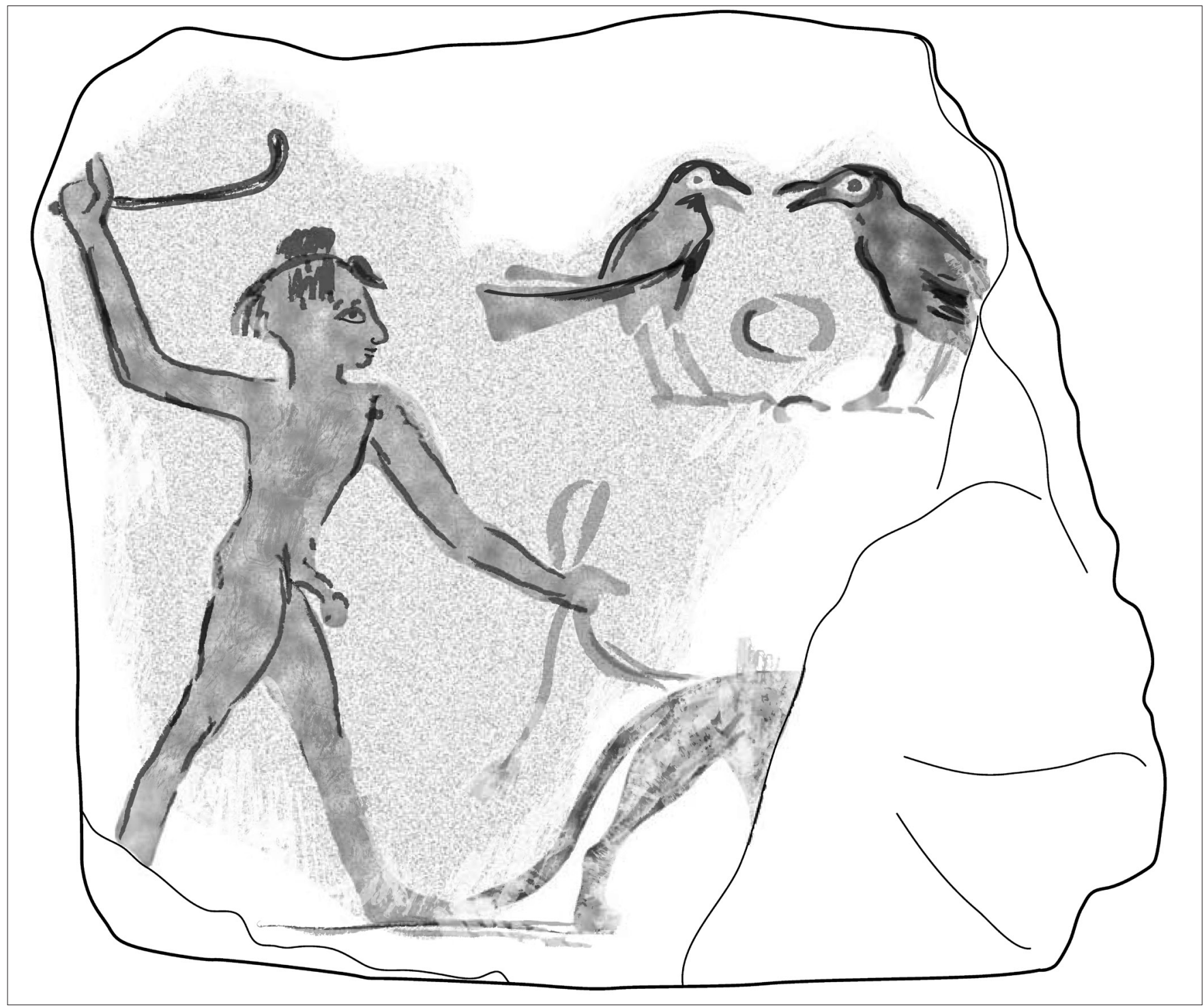

Obr. 3. Anonym, „Chlapec pohánějící paviána a dvě hašteřící se vrány“, mezi lety 1292-1078 př. n. 1., 19.-20. dynastie, kresba na vápencovém ostraku, rozměry 10x11,3 cm, naleziště: Dér el-Medína (?), Egypt, uloženo: nezjištěná sbírka.

Nahý chlapec s holí ve zvednuté pravé ruce pohání ochočeného paviána, kterého drží levou rukou na vodítku, zatímco vpravo nahoře soupeří dvě vrány o nějaký plod (datli, fík či ořech palmy dumové) nebo vejce. (Kresba: Jolana Malátková.)

Fig. 3. A limestone ostracon depicting a naked boy driving a trained baboon (Papio hamadryas) and two large black crows which are facing each other, with a fruit or an egg placed between them. Between 1272-1078 BC, Dynasty 19-20, dimensions 10x11.3 cm, from Deir el-Medina (?). Collection not found. (Drawing: Jolana Malátková.)

„Nehanob, Pane, umírající tèlo, aby u plačicích žen práchnivělo, at'v poušti skončím dráhu svou: pár dravých ptáků nad hlavou, havran rve

mé rány krvavé."

S vyobrazením havrana se ve faraonském Egyptě setkáváme jen ojediněle. Výjimku tvoří kresby havranů (a/nebo vran) na ostrakách z Ramessovské doby (1292-1078 př. n. 1.), jež pocházejí zvláště z vesnice Dér el-Medíny, obývané královskými řemeslníky, kteří tesali a zdobili nádherné královské skalní hrobky v Údolí králů a Údolí královen. Ostraka - střepy hliněných nádob a úlomky vápence vždy sloužily jako snadno dostupný psací materiál, jehož se používalo k zachycování méně důležitých záznamů a ke školním účelům. $\mathrm{Na}$ tak zvaných figurálních ostrakách se potom setkáváme s různými neformálními kresbami lidských postav, zvírat a ptáků, stavebními náčrty a se satirickými nebo erotickými scénami. Na takových ostrakách bývají zachyceni i havrani stojící na datlové palmě, fíkovníku či palmě dumové a zobající jejich plody (Vandier d'Abbadie 1936, 2, tab. II; obr. 2) nebo třeba i soupeřící o nějaký plod nebo vejce (Davies 1917, 239, tab. LI.3; obr. 3). 


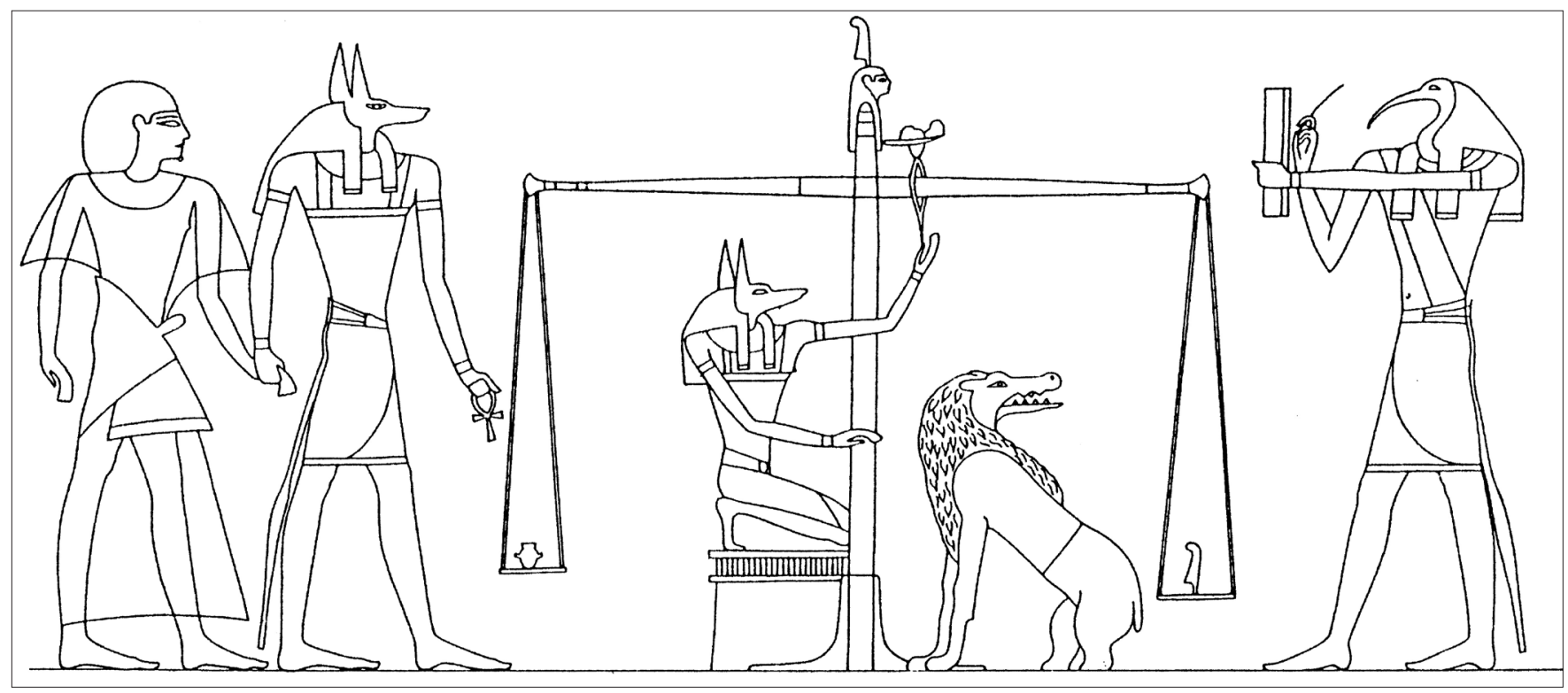

Obr. 4. Anonym, „Vážení srdce zesnulého“, kolem roku 1280 př. n. 1., 19. dynastie, malba na papyru, rozměry 19x43,3 cm, naleziště: oblast Théb, Egypt, uloženo Britské muzeum v Londýně, Velká Británie.

Scéna vážení srdce zemřelého při posmrtném soudu se nachází i na slavném papyru královského písaře Hunefera (z doby vlády Setchiho I., cca $1290-1279$ př. n. 1.) s textem a ilustracemi (tzv. vinětami) ke Knize mrtvých. (Kresba: Jolana Malátková.)

Fig. 4. Scene of weighting the deceased's heart in the Book of the Dead famous papyrus of the king's scribe Hunefer, cca 1280 BC, Dynasty 19 , dimensions $19 \mathrm{x} 43.3 \mathrm{~cm}$, Thebes. Now in the British Museum, London. On the left Anubis leads Hunefer in. A second figure of Anubis checks the balance while Thoth records the result and the "Great Eater of the Dead" stands at the ready. (Drawing: Jolana Malátková.)

Krajně zajímavá je satirická kresba na vápencovém ostraku s parodií posmrtného soudu, jehož klíčovou scénou bylo vážení srdce zesnulého v soudní síni Obou pravd (Vachala 2009, 200-201; obr. 4). Uprostřed síně stály váhy, na jejichž levou misku položil Anup, bůh zemřelých a ochránce pohřebišt’ se šakalí hlavou, srdce zesnulého, které představovalo jeho svědomí, zatímco na pravé misce spočívalo pštrosí péro, které bylo symbolem bohyně pravdy a spravedlnosti Maat. Výsledek vážení zapisoval na tabulku bůh vědění a moudrosti Thovt s ibisí hlavou. Zemřelý během vážení prohlašoval, že se za svého života nedopustil žádného zločinu proti lidem, králi, bohům ani zvířatům. Při vážení jeho skutků musela být pravda a svědomí v rovnováze. Jakýkoli lživý výrok by váhy vychýlil a svědomí by bylo lehčí než pravda. Pod váhou potom číhala obluda s hlavou krokodýla, přední částí těla lva a zadní částí hrocha, která se $\mathrm{v}$ př́ípadě viny zemřelého na nebožáka vrhla a pohltila jej. Smrt v jejích útrobách byla nejstrašnějším trestem, který znamenal smrt, tentokrát již skutečnou a neodvratnou. Pokud naopak vážení dopadlo dobře, ospravedlněného zemřelého přivítal bůh Usir a uvedl ho do své říše blažených mrtvých.

Na uvedeném ostraku (Houlihan 1988, 133, obr. 191; obr. 5) jsou na váze zobrazeni hroch (vlevo) a havran s roztaženými křídly (vpravo). Podle „obsazeni“ scény vážení srdce při posmrtném soudu zde autor přidělil hrochovi stojícímu na předních nohou důležitou úlohu lidského srdce (podle Egyptanů tedy myšlení, vědomí, svědomí), zatímco havranovi symbol pštrosího péra (tedy pravdy, spravedlnosti, morálky). Na samotné vážení přitom dohlíží kočka (vpravo), která je v postavení obludné a obávané Velké požíračky zemřelých, a sova v pozici boha Anupa. Uvážíme-li, že víra ve spravedlivý posmrtný soud (popsaný ve 125. ř́kadlu Knihy mrtvých: Vachala 2009, 200-211) a věčný blažený život na onom světě byla fluidem egyptského náboženství, pak tato kresba představuje vskutku odvážnou parodii.

Méně známá je skutečnost, že ve starém Egyptě byly oblíbeným literárním žánrem také bajky (Brunner-Traut 1980), v nichž přirozeně vystupují zvířata a ptáci jako personifikace různých rysů lidské povahy. Kromě toho, že některé máme písemně doložené, existuje i celý soubor papyrů a ostrak zvláště z Ramessovské doby s ilustracemi ke zcela neznámým bajkám. Patří mezi ně i kresba na tak zvaném satiricko-erotickém papyru Egyptského muzea v Turínu (Omlin 1973, 56, tab. XI, XIII-XVIII; obr. 6), která nás v souvislosti s tématem tohoto pojednání nejvíce zajímá. Kresba totiž znázorňuje hrocha na stromě, který trhá do košíku fíky, zatímco havran s roztaženými křídly k němu stoupá po žebříku ... Zatím však nejsme schopni podat žádný bližší výklad úlohy tohoto havrana (nikoli vlaštovky, jak někteří egyptologové uvádějí).

Naprosto jedinečné je zpodobení dvou havranů na uzavřeném zlatém pektorálu provedeném typicky egyptskou technikou přihrádkové inkrustace (Aldred 1971, 213-214, tab. 80-81; obr. 7). Jde o vrcholné šperkařské dílo z poloviny 12. dynastie (okolo 1900 př. n. 1.), nalezené v šachtě hrobky č. 124 v hornoegyptské lokalitě Rikka v roce 1913. Pektorál má podobu svatyně, jejíž strop tvořený dvěma svatýma Horovýma očima (vedžat) a slunečním kotoučem podpírají po obou stranách papyrusové rostliny. Uprostřed se nachází žezlo (nehbet) 


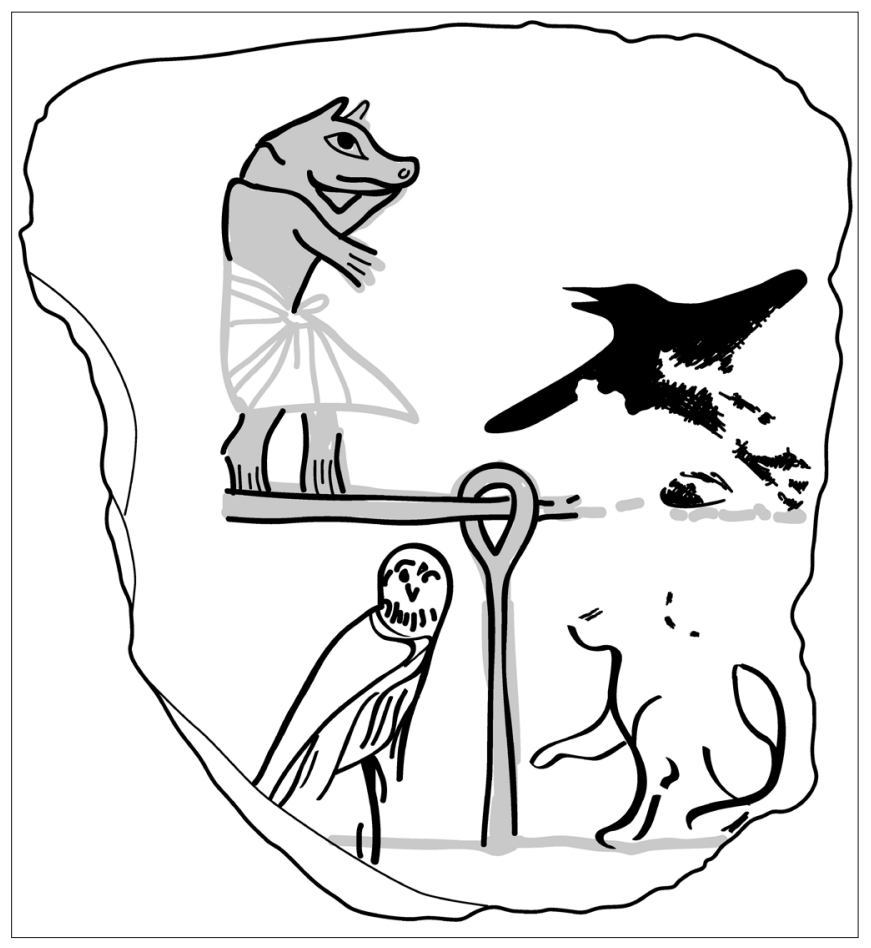

Obr. 5. Anonym, „Vážení srdce zemřelého ve zvírecím podáni“, mezi lety 1292-1078 př. n. 1., 19.-20. dynastie, kresba na vápencovém ostraku, rozměry 7,8x7,4 cm, naleziště: Dér el-Medína (?), Egypt, uloženo: nezjištěná sbírka. Neznámý autor si dovolil parodii scény vážení srdce zemřelého člověka při posmrtném soudu, když zobrazil vyvažování hrocha (v úloze lidského srdce představujícího pozemské skutky zesnulého) a havrana (v zastoupení pštrosího péra bohyně spravedlnosti Maat) za přítomnosti sovy a kočky. (Kresba: Jolana Malátková.)

Fig. 5. Drawing of a limestone ostracon showing what is seemingly a parody of the traditional scene of weighting the deceased's heart (Book of the Dead, chapter 125). The hippo and the raven are depicted standing on either end of the scale, while below, an owl and a cat serve as the judge and the "Eater". Between 1292-1078 BC, Dynasty 19-20, dimensions 7.8x7.4 cm, Deir el-Medina (?). Collection not found. (Drawing: Jolana Malátková.)

v podobě lotosového poupěte, jehož se zobáky dotýkají dva havrani stojící vpravo i vlevo na hieroglyfické značce (nub) představující zlatý náhrdelník se zavěšenými perlami. Jelikož havrani v této oficiální scéně zastupují sokoly ztělesňující vládnoucího krále, nečekaně zde vystupují v úloze mocných ochránců.

Ve staroegyptských písemných pramenech se - na rozdíl od ikonografických - dochovala pouze jedna jediná zmínka o havranovi, a to $\mathrm{v}$ negativním smyslu. $\mathrm{V}$ démotickém snáři zaznamenaném na papyru Carlsberg č. XIV, f. (Ny Carlsberg Glyptotek v Kodani) z 2. století n. 1. se totiž uvádí (Volten 1942, 98-99, tab. 7):

"Jestliže (se jí zdálo, že) přivedla na svět havrana, pak (porodí) postižené (dítě)."

Pro úplnost však ještě připomeneme, že řecký spisovatel Klaudios Ailiános (asi 175-235) přiřkl (VII, 18) bohovi Apollónovi uctívanému $\mathrm{v}$ hornoegyptském Kuftu příznivou podobu posvátného havrana. Podle egyptského učence Hórapollóna

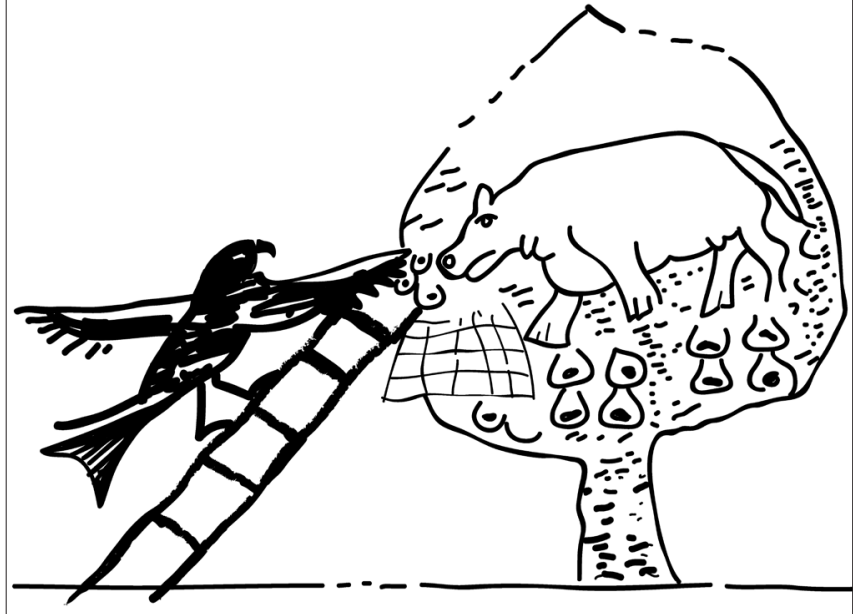

Obr. 6. Anonym, „Ilustrace k neznámé bajce“, kolem roku 1150 př. n. 1., 20. dynastie, kresba na papyru, rozměry $5,2 \times 7,5 \mathrm{~cm}$, naleziště: oblast Théb, Egypt, uloženo: Egyptské muzeum v Turínu, Itálie.

Kresba havrana stoupajícího po žebříku na fíkovník, v jehož koruně hroch trhá do košíku fíky, představuje ilustraci $\mathrm{k}$ neznámé staroegyptské bajce. Kresba se nachází na papyru společně s dalšími satirickými a erotickými scénami. (Kresba: Jolana Malátková.)

Fig. 6. A scene from the so-called "Satirical and Erotic Papyrus" showing a raven climbing a ladder to reach a sycamore fig tree. Already perched up in the tree is a hippo gathering the ripe figs into a basket. An episode from an unknown fable. Cca 1150 BC, Dynasty 20, dimensions $5.2 \times 7.5 \mathrm{~cm}$, Thebes. The Egyptian Museum, Turin. (Drawing: Jolana Malátková.)

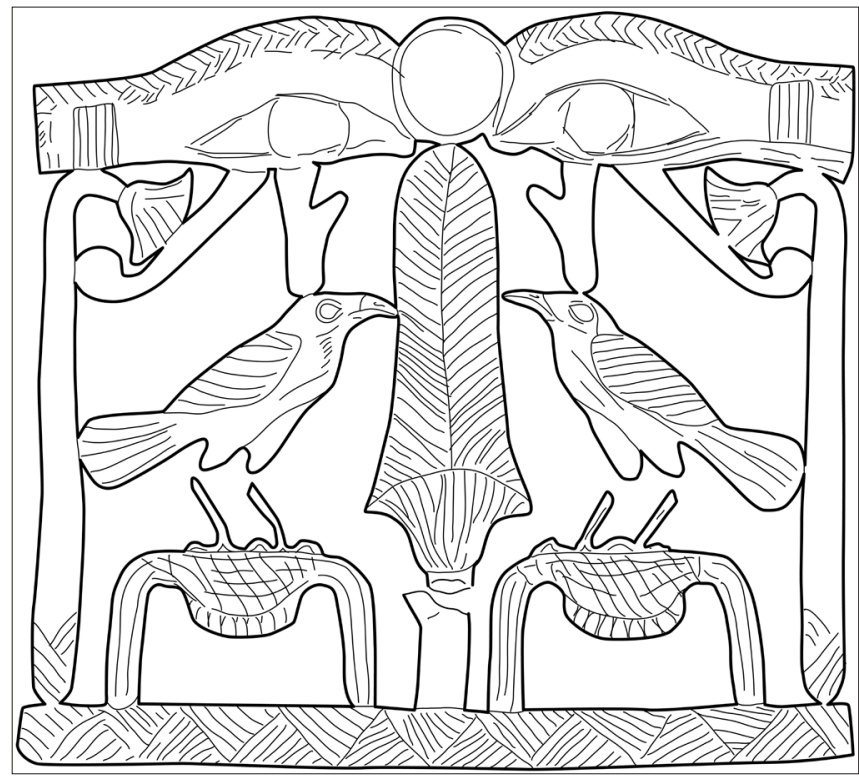

Obr. 7. Anonym, „Pektorál“, okolo roku 1900 př. n. 1., 12. dynastie, zlato, karneol, lapis lazuli, tyrkys, rozměry $3,8 \times 4,5 \mathrm{~cm}$, naleziště: Rikka, Egypt, uloženo: Muzeum v Manchesteru, Velká Británie.

Pektorál v podobě svatyně se dvěma havrany (stojícími na zlatých náhrdelnících), svatýma očima, slunečním kotoučem, žezlem uprostřed a papyrusovými rostlinami po stranách patři mezi špičková staroegyptská klenotnická díla. Podle oficiální ikonografie zde havran nahradil „zlatého sokola“ - egyptského krále. (Kresba: Jolana Malátková.)

Fig. 7. A shrine-shaped pectoral depicting two ravens in place of the falcons perched upon the nub-signs, as representing the god Horus, incarnated in the king (the "Golden Falcon"). Gold inlaid with carnelian, lapis lazuli and turquoise. Cca 1900 BC, Dynasty 12, dimensions $3.8 \times 4.5 \mathrm{~cm}$, el-Riqqa. The Manchester Museum. (Drawing: Jolana Malátková.) 
(I, 8), který žil zřejmě na přelomu 4. a 5. století, zase byli řecký bůh války Arés a řecká bohyně smyslné lásky a krásy Afrodíté zobrazováni jako dvě vrány.

A konečně zmíníme i řeckou lidovou knihu Fysiologus, jejíž vznik (zřejmě v Alexandrii) se klade do 2. století. Tato velmi oblíbená kniha byla následně přeložena do řady jazyků včetně koptštiny, posledního vývojového stupně egyptštiny. Mezi popisy a výklady pozoruhodných vlastností různých zvířat v ní nechybí ani zmínka o tom, jak si „havranice“, důsledně zachovávající věrnost svému havranovi, drápem rozdrásá jazyk, aby nemohla krákat a přivolat si tak pomoc $\mathrm{v}$ případě ohrožení svým vlastním druhem (Störk 1984, 75).

$\mathrm{Z}$ jazykového hlediska je zajímavé, že se nikde nedochovalo egyptské slovo pro havrana nebo vránu. Známe ho teprve v démotické podobě abek, kde takto znělo i vlastní jméno (dnes bychom tedy řekli pan „Havran“), a v koptské podobě abók (Černý 1976, 2). Arabské označení havrana ghuráb však egyptologové dobře znají z místního jména dnes již neexistující vesnice Abú Ghuráb („Otec havranư“) na západním břehu Nilu, asi $20 \mathrm{~km}$ jižně od Káhiry. Na okraji písečné Západní pouště se zde totiž nacházejí velkolepé opuštěné rozvaliny slunečního chrámu panovníka 5. dynastie Niuserrea z doby okolo 2445 př̀. n. l. (Bissing 1905, 1923, 1928; Voss 2010).

Sám se občas rád vydávám z Abúsíru do tohoto místa ztraceného v poušti, které má neopakovatelnou atmosféru: je možné se tu nerušeně toulat a prožívat genia loci třeba chrámové Síně ročních období, do jejíchž vápencových stěn byly kdysi vytesány jedinečné malované reliéfy přibližující proměny přírody během tří střídajících se staroegyptských ročních období (Edel - Wenig 1974; Finneiser 2010). I stvořitel světa a dárce života Re by se jistě podivil, že tyto skvostné reliéfy z jeho chrámu v Abú Ghurábu se po téměř 4400 letech dostaly do Egyptského muzea v Berlíně ... Při přemítání tu našimi jedinými společníky mohou být právě havrani a vrány, i když jako laici těžko rozeznáme, ke kterému ze šesti druhư žijících v dnešním Egyptě náleží (Houlihan 1988, 131, 166: Corvus splendens, C. frugilegus, C. corone, C. ruficollis, C. corax, C. rhipidurus).

$\mathrm{V}$ pouštní samotě si dobře uvědomíme a nejlépe pochopíme tíhu rozluky a truchlení, jejichž působivým symbolem se stal především havran, který také $\mathrm{v}$ daném kontextu nemůže chybět ve staroarabské poezii, ani v arabské lidové poezii. A tak například pronásledovaný a $\mathrm{z}$ Medíny vyhoštěný básník milostné lyriky al-Ahwas (655-728) emotivně popsal pusté ležení a zoufání opuštěného milého slovy (Petráček 1975, 47):

\author{
„Odešla. \\ Pusté ležení \\ jak ohlodaná kost. \\ Jen vitr \\ sype písek, \\ nános na nános. \\ Sbohem. \\ Pak jsme ho spatrili. \\ Plakal uprostřed jejího tábora
}

a zůstal

hluchý,

neslyšel ani,

jak havran loučení krákorá."

A co dodat $\mathrm{k}$ prosté a upřímné lidové básničce vybízející dívky k truchlení, když je potkala bolest rozloučení (Kubíčková - Petráček 1954, 90):

„Ó dívky, dívky, zřeknète se nových šátků,

truchlete, dívky, nevycházejte v den svátku.

Dnes dívky, barvu na vlasy vám zakázali,

truchlete, nejsou pro vás už kašmírské šály.

Ó dívky, co vás potkalo dnes za trápení?

U vašich dveři kráká havran rozloučení."

Můžeme říci, že dávní obyvatelé země na Nilu vnímali havrana jako součást živé př́rody, která je obklopovala. Jeho realistická kresba se proto někdy vyskytla na ostraku, kde byl havran nebo vrána součástí krajinného výjevu. Dvakrát se havran objevil v satirickém kontextu: jednou šlo o parodii (!) vážení srdce zesnulého při posmrtném soudu, podruhé o ilustraci k neznámé bajce. Zcela přirozené bylo jeho znázornění, kdy společně se supy trhal mrtvá těla bojovníků, což ovšem vzbuzovalo odpor, podobně jako zlý sen ženy, které se zdálo, že porodila havrana. Na druhé straně se dochoval krásný zlatý pektorál s vyobrazením dvou havranů, kteří symbolizovali faraona, a vystupovali tudíž jako mocní ochránci toho, jenž tento šperk nosil zavěšený na krku.

Egyptané tedy rozlišovali pozitivní a negativní aspekt havrana. Byl to pro ně př́klad toho, jak jedna bytost nebo jev může v sobě zahrnovat dobré a zlé. Právě tak uctívali přírodní síly pro jejich blahodárnost i zkázonosnost. Také svým boho̊m mnohdy přisuzovali kladnou i zápornou povahu (například uzdravující a zároveň krvelačná lví bohyně Sachmet). Je zajímavé, že protikladné vnímání havrana přetrvávalo v Egyptě a na Arabském poloostrově i nadále: pro staroarabské básníky byl havran symbolem rozloučení, smutku, neštěstí a smrti, zatímco v arabském lidovém myšlení byl naopak znamením naděje a dobra.

Tento článek byl napsán pro připravovanou knihu Stáni Bártové Uhranutá havrany (Brno: Akademické nakladatelství CERM, 2012).

\section{LITERATURA}

Aldred, Cyril (1971): Jewels of the Pharaohs. Egyptian Jewellery of the Dynastic Period. London: Thames and Hudson.

Bissing, Friedrich Wilhelm von (1905, 1923, 1928): Das Re-Heiligtum des Königs Ne-woser-Re (Rathures). I: Der Bau, II: Die kleine Festdarstellung, III: Die grosse Festdarstellung. I: Berlin: Dunckler. II: Lepzig: J. C. Hinrichs. III: Leipzig: J. C. Hinrichs.

Brunner-Traut, Emma (1980): Altägyptische Tiergeschichte und Fabel. Gestalt und Strahlkraft. 6. vydání. Darmstadt: Wissenschaftliche Buchgesellschaft.

Černý, Jaroslav (1976): Coptic Etymological Dictionary. Cambridge: Cambridge University Press. 
Davies, Norman de Garis (1917): Egyptian Drawings on Limestone Flakes. In: The Journal of Egyptian Archaeology, roč. 4, s. 234-240.

Edel, Elmar - Wenig, Steffen (1974): Die Jahreszeitenreliefs aus dem Sonnenheiligtum des Königs Ne-user-Re. Berlin: Akademie-Verlag.

Finneiser, Klaus (2010): Die Bilderwelt im Sonnenheiligtum des Pharao Niuserre. In: Brinkmann, Vinzenz, ed., Sahure. Tod und Leben eines grossen Pharao. Frankfurt am Main: Liebieghaus Skulpturensammlung.

Houlihan, Patrick F. (1988): The Birds of Ancient Egypt. Cairo: The American University in Cairo Press.

Kubíčková, Věra - Petráček, Karel (1954): U studny Zemzem. Arabská lidová poesie. Praha: Státní nakladatelství krásné literatury, hudby a umění.

Malek, Jaromir (2003): Egypt: 4000 Years of Art. London: Phaidon Press.

Moers, Gerard et al. (2004): Der König als Bezwinger der Chaos. In: Petschel, Susanne - von Falck, Martin, eds., Pharao siegt immer. Krieg und Frieden im Alten Ägypten. Bönen: DruckVerlag Kettler, s. 25-41.

Oliverius, Jaroslav (1995): Svět klasické arabské literatury. Brno: Atlantis.

Ondráš, František (2003): Moderní egyptská próza v osmdesátých a devadesátých letech dvacátého století. Praha: SETOUT.

Omlin, Joseph A. (1973): Der Papyrus 55001 und seine Satirisch-erotische Zeichnungen und Inschriften. Torino: Edizioni d'Arte Fratelli Pozzo.

Petráček, Karel (1968): Román o Antarovi. Staroarabská romance. Praha: Odeon.

Petráček, Karel (1975): Cestou karavan. Praha: Československý spisovatel.

Petráček, Karel (1977): Básníci pouště. Arabská poetika devíti století. Praha: Československý spisovatel.

Růžička, Rudolf (1930): Duraid ben as-Simma. Obraz středního Hidžâzu na úsvitě islámu. 2. díl. Praha: Česká akademie věd a umění.

Störk, Lothar (1984): Rabe. In: Helck, Wolfgang - Westendorf, Wolfhart, eds., Lexikon der Ägyptologie, V. Wiesbaden: Otto Harrassowitz, s. 74-75.

Vachala, Břetislav (2009): Staroegyptská Kniha mrtvých. Překlad. Praha: Dokořán.

Vandier d'Abbadie, Jeanne (1936): Catalogue des ostraca figurés de Deir elMédineh, I. Le Caire: IFAO.

Volten, Aksel (1942): Demotische Traumdeutung (Pap. Carlsberg XIII und XIV verso). Kopenhagen: Einar Munksgaard.
Voss, Susanne (2010): Das Sonnenheiligtum des Pharao Niuserre. Ein einzigartiger Tempeltyp im Alten Reich. In: Brinkmann, Vinzenz, ed., Sahure. Tod und Leben eines grossen Pharao. Frankfurt am Main: Liebieghaus Skulpturensammlung.

\section{AUTOR}

Vachala, Břetislav (27. 7. 1952, Jaroměř), český egyptolog, profesor egyptologie v Českém egyptologickém ústavu Filozofické fakulty Univerzity Karlovy v Praze a Káhiře, v němž působí od roku 1975 dosud (s přestávkou v letech 1993-1997, kdy zastával post velvyslance České republiky v Egyptě a Súdánu). Zaměřuje se na egyptskou filologii, literaturu, dějiny a archeologii, které též přednáší na Filozofické fakultě Univerzity Karlovy v Praze. Publikuje epigrafické a ikonografické prameny ze 3. tisíciletí př. n. l., objevené při českých archeologických výzkumech v Abúsíru, jichž se účastní od roku 1979. Zpracovává staroegyptské památky z českých muzeí a sbírek. Věnuje se překládání a vydávání staroegyptských literárních děl. Je autorem monografií, vědeckých studií v zahraničních egyptologických periodikách, encyklopedických hesel, učebních textů, populárních článků a recenzí. Poslední vydané knihy: Staroegyptská Kniha mrtvých (Praha: Dokořán, 2009), Staří Egyptané (2. vydání, Praha: Libri, 2010), Lékařství starých Egyptanů I: staroegyptská chirurgie, péče o ženu a dítě (společně s Eugenem Strouhalem a Hanou Vymazalovou, Praha: Academia, 2010).

Kontakt: Prof. PhDr. Břetislav Vachala, CSc., Český egyptologický ústav Filozofické fakulty Univerzity Karlovy v Praze, Celetná 20, 11000 Praha 1,

e-mail: bretislav.vachala@gmail.com; bretislav.vachala@ff.cuni.cz. 
